данности и отличий от известных ранее. Выпадая из поля зрения, сама жизнь эстетического - условие и мерило развития человеческой сущности - делает такие исследования неспособными к настоящей экспертности, прежде всего, к определению действительного культурного веса художественно-эстетического явления и перспектив его дальнейшего существования. Насущность признания этой проблемы и ее обязательного последующего решения сточт в ряду неотложных задач культурологии на пути ее окончательного утверждения как смыслового центра гуманитаристики.

Ключевые слова: эстетическое, социокультурные практики, историческая существенность периода, человекомерность, человекомотивированное значение, экзистенциальный опыт, духовные ниши, Contemporary Art, микротопии, художественный акционизм.

I. V. Zhyvohliadova, Ph.D., Assosiate Professor Taras Shevchenko National University of Kyiv, 60, Volodymyrska Street, Kyiv, 01033, Ukraine irinavictz@gmail.com

\title{
CULTURE AND PERSONALITY: R. WAGNER "BETWEEN MUSIC AND LIFE"
}

\begin{abstract}
Modern trends in the development of culture, its artistic component, have actualized the issues of in-depth study of the world and national heritage. The article analyzes the creation of an outstanding personality - R. Wagner (1813-1883), with its inherent contradiction, complexity, versatility, as a representation of the creative potential of a person's participation in the processes of cultural creation. An integrative, culturological analysis of the specifics of his composing activity as a cultural phenomenon makes it possible to highlight the role of an artist, thinker, reformer in the space of functioning of a certain cultural, in this case romantic, tradition, to explore the subjective experience of transforming art into a cultural practice of improving society. Through the works of a German composer, the anthropo-creative potential of interaction between culture and personality is analyzed. Concentrating all the trends and crises of romanticism in the music of the second half of the XIX century, the work of the composer as a reformer demonstrates current creations of the relentless desire to transform the world around, which encourage artists to different creative reactions to the collision of modern life, which, in turn, involves others in understanding its essence.

Key words: R. Wagner, creative personality, reformism, culture of romanticism, musical culture, operatic creativity, musical drama.
\end{abstract}

Formulation of the problem. Current trends in the development of culture, its artistic component, have exacerbated the relevance of in-depth study of world and national heritage. The issues of our time motivate us to take a new look at the history of culture. Over time, great works of the past reveal to us social and human experience in the relevant and deep meaning. These works, although originated in other historical conditions, are created by the eternal questions that concern modern society. Art continues to ask people questions about the meaning of life, about truth and justice, about the nature of world evil and the need for a new reconstruction of the world, strengthening its humanistic basis.

"In his artistic works, R. Wagner solved the same problems and antinomies that tore Europe of the XIX century and were expressed differently in different spheres of consciousness, theoretical and artistic culture, with his own means. That is, the ground on which Wagner grew up were events of truly world-historical significance: the bourgeois transformation of economic, political, etc. living conditions of the human individual, given the prospects that this transformation gives for this individual... Throughout his life Wagner shared all the main illusions of this process, giving them an extremely sharp artistic expression" [5]. The study of the life of an outstanding personality $-\mathrm{R}$. Wagner (1813-1883), with its inherent contradictions, complexity, versatility, allows us to understand the activities of a talented artist as a representation of the artistic potential of creative personality in cultural processes.

Analysis of research and publications. The problem of the interaction of culture, in particular the romantic and creative personality of the German composer, cultural figure was and still is the object of close attention of representatives of various fields of scientific knowledge. At the same time, research, which is based mainly on the material and conceptual schemes of musicology (the works of Alshwang A., Borovik S., Druskin M., Hanslik E., Krauklis G., Larosha G., Lobanova M., Levik B., Pluzhnikov V., Tumanina N., Schure E. and others), is dominating.

Understanding the culture of romanticism, its theory and artistic practices is carried out in the studies of Bent M., Volkova I., Gabitova R., Klyuyeva I., Ligus O., Kashuba M., Nalyvayko D., Stepanova V., Sidorenko L., Shestakova V.,
Yaskiva O. and others. Questions of the personality of Wagner - the artist in the context of cultural history are covered in the works of Gruber R., Glazenapp K., Kappa Y., Lishtanberg A., Marcus S., Oliynyk S., Sidorova O. A large number of studies on various aspects of the interaction between the spiritual world and creativity of the composer, as "titan of the spirit", "owner of thoughts"of many artists and thinkers of subsequent generations were done (Gachev D., Dilthey V., Devyatova N., Ivashchenko T., llenkov E., Losev O., Makarenko G., Nietzsche F., Samsonova T., Cherkashina-Gubarenko M., Shapoval O

Purpose of the article is to analyze the works of Wagner as an example of anthropo-creative potential of the interaction between personality and culture. Integrative, culturological analysis of the specifics of the composer's creative activity as a cultural phenomenon allows to highlight the role of artist, thinker, reformer in the space of a certain cultural tradition, to explore the subjective experience of transforming art into a cultural practice of modification and improvement of society.

Exposition of the main material of the study. The artist's talent allows us to return the fact of objective reality to a perspective in which his universal singularity would "play" in the light of the general perspective of development. Creativity is a way that expands the possibilities of the creative personality in the disclosure of many different aspects of life. Discovering them, the creative personality expands the horizons of individual experience, acquires elements of new self-awareness. This, in turn, leads to renewed action. At the same time, the creator enriches reality itself, developing its internal potentials, creating values of a fundamentally new quality. From the very beginning, creative activity is organized and regulated by forms that have a "universal" character. These forms, in turn, are the product of the same long "discipline" as logical forms, categories of logic. At the same time, in free creativity there is always a more or less obvious individual variation of those forms of activity that are already formalized, expressed in rigidly unambiguous formulas.

E. llyenkov wrote, that Wagner's works "became a kind of "phenomenology of the spirit" throughout the nineteenth century - a process of successive change from one state of this spirit to another; each of these states is nothing 
more than a very sharply generalized and typical way of how a human individual perceives the world in conditions of the bourgeois-capitalist transformation of all relations between people" [5]. The life circumstances of Wagner's childhood and adolescence opened up a wide humanitarian and cultural perspective for him. Literature, music, theater were the professional hobbies of his relatives and acquaintances. The tendency to a fantastic, mystical view of the world was supported mainly by the works of Hoffman, Shakespeare, folk tales. The rebellious, romantic Wagner admired the serene beauty of ancient Greek art, studied Greek mythology and literature. One of the heroes of the composer's childhood was the great Luther. Later, the artist's interest in the Reformation era, the image of Luther found expression in his opera. Among the heroic operas he conceived (but did not write) in German history was an opera dedicated to Luther. About two decades later, R. Wagner wrote the opera "Die Meistersinger von Nürnberg", where along with the typical but non-existent in real life heroes are twelve great masters of the $\mathrm{XVI}$ century. The central image of the opera is Hans Sachs, who wrote a poem about Luther. This verse became a kind of "hymn of the Reformation."

Wagner's life was full of great events: the Dresden Revolution, in which the composer was directly involved as Bakunin's aide (later Wagner repeatedly admitted that his Siegfried from "The Ring of the Nibelung" was written similar to him), the defeat of the revolution and the arrival of close friends in the prison, fleeing Germany due to the threat of the death penalty, without money, with false documents, then - life in exile. Therefore, it is no coincidence that Wagner's reference to the plot of "Der fliegende Holländer", in which the composer saw his own fate as an eternal exile who is incomprehensible to anyone and nowhere and who seeks peace in vain [3].

In the process of creativity, expanding the space of realization of his own spiritual potential, the artist reveals the horizons of human existence. He "grasps" the possibilities of the objective world in their necessary connection with the dialectic of social life, engraves them as real with the help of art forms. The creation of each work of art is preceded by a process of in-depth study by the artist of his life, prospects for its development, understanding, generalization of observations and impressions. The more voluminous, deeper the artist's knowledge of life, the more successfully his talent develops, because in the end it is this "baggage" that the artist processes, creates new images based on it.

Awareness and perception of reality by the artist, in contrast to everyday vision, is characterized by a special focus. It is organized by certain attitudes that focus on getting some kind of impressions, and differentiate them. The habit of constant, tireless observation of life and oneself, the artist's inner desire for creativity, the expression of his attitude to the world through works of art determine the nature of the systematization of life material. Talent is distinguished by the ability to look at the world "with a view to the future." Externally elusive connections of objects and phenomena are grasped, which allows us to see the unusual in the ordinary, in part - the whole, in the present - the past and future. These connections stimulate creative innovations.

The nature of a certain connection of artistic images, their content is determined by the artistic concept of the author, his desire to somehow reveal the fact of existence, which he is interested in. It should be clarified that the influence of ideals is not direct. The connecting link is the worldview. The artist feels the pressure of the whole sociocultural context, and is often unaware of the sources of emotional and rational orientations.
R. Wagner's work is "a very natural and very vivid reflection of the epoch. And the era of seriousness and meaningness [5]. Sharpened attention to social contradictions directed the musician - romance on the path of "universal" coverage of life and, at the same time - romantic closeness. As a result, the whole artistic approach to reality has changed. Before him, as for other composers - romantics in a new way, different from the classics, there was a problem of creative method, which would comprehend and reproduce all these contradictions and create a new, free world of romantic music. In the romantic art of music we see a different way than in classicism, a way of artistic generalization, addressing subjectivity, emotionality, fiction and dreams, freedom of form, folklore and national history, creating new ways of artistic expression and image, transforming those who were the establishment of classicism. A characteristic feature of German Romanticism, which avoids the clarity and certainty that were inherent in Enlightenment classicism, - is the deep concealment of the main idea under the guise of the Middle Ages, fiction, symbol. In the world of the distant past, romantics sought models of the ideal social order. Emotional madness, exciting exaltation, pathos, deep psychology and philosophical depth distinguished the figurative thinking of the Romantics. Romantics were interested in a person who is separated from the specifics of his daily life. Moreover, the romantics of metaphysical composition were interested in the realm of the unreal, the supersensible. All these features distinguished R. Wagner, moreover, they have grown as much as possible in him, which gives musical images, grand scale, emotionality and tragedy.

"Wagner carried on his shoulders the heavy burden of the romantic world of feelings, historical costumes, scenery. And a romantic is obliged to take everything with the utmost seriousness - himself and his feelings"[3]. The whole reality of socio-political catastrophes was experienced by Wagner deeply personally. Impressions of the surrounding reality gradually accumulated in the minds of the artist and required their artistic embodiment - it was necessary to "capture" the present and sensitively, honestly express its new representative forms.

Developed thinking and perception allowed Wagner to see the whole before recognizing its parts. A striking example is The Ring of the Nibelungen, an unusually strong, allegorical, embodiment of the tragedy of modern Wagner's life, controversial in its hopes, aspirations and meanings for human existence.

The revolution, which European society spent several centuries preparing for, did not live up to expectations for the future and did not leave enough consequences. Wagner was very worried about this situation, moreover, he generalized it as much as possible and reflected it with great enthusiasm. One of the most striking monumental responses of the composer was his operatic heritage, which entered the treasury of world culture, having no analogue in the history of human culture. During the revolutionary events of 1848 , Wagner created the heroic image of the national hero Siegfried, the image of Wotan - a suffering man who is prone to philosophizing, but not to action suppressed by the evil and injustice he saw around. "Wotan is like us to the smallest detail", - Wagner wrote: "He is the vault of all the intelligence of our time"[6].

As it is known, to reach the level of requirements for the artistic word, the artist needs the ability to think and feel images, vivid paintings that excite others, to pass them through his own heart, which is excited by the issues of the era, to be at the center of all human experiences. The composer fills the space of musical images with a living stream of reality, the content of which largely depends on 
his own life experience, on his abilities, aspirations, knowledge. The holistic coverage of the phenomena of life is organically connected in the creator with the emotionality of perception, which makes it impossible to be indifferent, to be an outside observer. An active attitude to any manifestations of life helps the creator to keep in his memory and restore a variety of images.

Any image, the plot becomes close to Wagner in connection with certain personal experiences and thoughts. In the German art of the first half of the XIX century a great place was occupied by chivalrous romance. In the prerevolutionary years, interest in the past history of the German people was increased significantly due to the dominance of the idea of German unification and the growth of national identity. Wagner, based on the work of the Brothers Grimm and other writers and historians, carefully studied the German Middle Ages. But, unlike many German romantics, Wagner did not try to idealize the Middle Ages. It played in his works the role of an external poetic shell, through which one can see the modern meaning (example - the opera "Tannhäuser").

Wagner himself admitted that the image of Tannhauser embodied one hundred percent of the modern German. In this character, it is easy to find the personification of modern Wagner, a man who suffocates in the webs of the surrounding society, seeking for his change. Wagner's tragedy was the realization of the unattainability of cherished ideals in the society of that time. Here the lyrical pathos of Tannhauser appeared.

Determining the ideological content of Wagner's operas is a difficult task due to the intertwining of the actual plot, modern social and autobiographical moments. Based on a myth or a medieval legend, Wagner uses only their plot basis. It changes and expands the ideological content in the direction of approaching modern issues. "Mythology, according to Wagner, is just a form of consciousness, in which for centuries and even millennia, the most general principles of worldview, characteristic of "the people as a whole" are crystallized. Myth is a quintessence of people's self-consciousness. In the system of mythological images "the essence of the world", as understood by the people, the ideals or images that people spontaneously seek to implement, are expressed" [5]. His works reflected the mythologized anticipation of future great cataclysms, which, in turn, required high moral asceticism from those who were destined to create a new great society of the future. At the same time, one or another plot became close to Wagner due to certain personal experiences and thoughts. Myth, according to Wagner, relieved him of the obligation to be precise and provided an opportunity to express what he thought was characteristic of music: philosophical and psychological meanings on a universal scale.

"He greedily attacked the ancient epic,... began to develop it... On a national basis, Wagner turned the heroes of his operas into universal heroes, namely - the heroes of perishing culture and the heroes of individualistic untruth in the face of objectively evolving reality" [6]. Actualization of the epic, the transfer of the meaning of the conflicts of the past to the modern Wagner world, "inscription" of epic images in the context of socio-philosophical problems of the second half of the nineteenth century was made by the artist with his characteristic originality of artistic vision of the world. In the mythological plot, he found "a whole connection of phenomena in a concise form" [2].

With his heroes, their destinies, Wagner expresses the general problems of life, while creating images of great emotional and psychological richness. Wagner's art is deeply rooted in national and folk traditions, and this is what allows him to rise to the universal level. Widespread interest in national mythology is determined by social circumstances in Germany. The idea of German unity, which opposed the disunity of the Germans in the face of feudal fragmentation, was supported by national myths and legends. It is no coincidence that Siegfried became a favorite hero of the advanced German youth. Sieglinde ("Ring of the Nibelungen") is one of Wagner's most typical heroines - tender, impulsive, painfully in love. This image embodies certain characteristics of Wagner's images - people with sensitive inner world, often controversial in their thoughts and actions. It is also important that none of Wagner's heroes is only on the one side of good and evil - he can connect his destiny with one of these two ethical principles, make a choice and can fluctuate between them, it can be broken by contradictions, but in what is evil, and what is good - Wagner has no doubt. Because of this, Wagner's characters are often cross-influenced by two opposing forces. Examples are Wotan, Tannhauser, Elsa, Tristan, Isolde, who are characterized by emotional conflict, controversial actions.

Music, with its specific way of reflecting reality, the peculiarity of musical form, that conveyes the external or internal movement of feelings, emotions, experiences allowed the composer to find an analogue of those ideas, which is the main mystery of Wagner's art. While transmitting the experiences of his characters, their generalized characters, appearance, environment in which they operate, Wagner finds an opportunity to convey purely musical means non-musical objects that create a system of leitmotifs.

By the power of his compositional skills, Wagner directed the thoughts and feelings of listeners to those future times when, in his opinion, due to the free association of mankind, those factors that destroy art will disappear. Naturally, to see the phenomena of life in one's own way does not mean to create them. The originality of the object is not born, but revealed by the individual. Hegel emphasized: "Originality, on the one hand, reveals to us the true soul of the artist, and on the other hand, gives us nothing but the nature of the object, so that this originality of the artist acts as the originality of the object and follows from it as well as subject of productive activity of the subject" [4, p. 306]. R. Wagner's works emerged as a kind of author's vision of contemporary culture, which, due to its individualistic nature, awaits, according to the composer, a sad future. Consistently believing that the modern world has no positive development, Wagner provided his explanations, decisions and methods of "salvation", which were essentially utopian. His position was typical to a wide circle of the bourgeoisie and the German intelligentsia. Understanding Wagner's works required mental effort, intellectual insight, absolutely necessary in order to comprehend its spiritual meaning, not accidental, private, but - lifelong human sense. This, in turn, provided an opportunity to get rid of the tragedy of loneliness, pessimism, to learn how to turn the "Schopenhauerian will" into a meaningful action, to learn to use it to make a change and improve the world.

Conclusion. R. Wagner's life occupies a prominent place in the musical culture of mankind. With its inherent contradictions, complexity, versatility, it is a vivid representation of the artistic potential of creative personality in the processes of cultural creativity. Integrative, culturological analysis of the specifics of Wagner's compositional activity as a cultural phenomenon allows us to highlight the role of artist, thinker, reformer in the space of a certain cultural, including romantic, tradition, to explore the subjective experience of transforming art into a cultural practice of modification and improvement of society.

An analysis of Wagner's works reveals how the composer, on the basis of the best examples of traditional art of 
the past and present, sought to adequately embody the problems he was aware of in artistic images, continuing practicing the great traditions and introducing significant innovations. These innovations, first of all, affected the opera genre, its figurative sphere. The development of culture very sharply revealed the dilemma of the contradictory position of the artist and art itself in the society of that time. R. Wagner's creative legacy emerged as a kind of author's vision of contemporary culture, which, due to its individualistic nature, awaits, according to the composer, a sad future.

The anthropo-creative potential of the interaction of culture and personality is analyzed on the example of the artist's life creativity. "Wagner directed a bright ray of knowledge to real and past lives, thanks to the fact that he discovered a relationship between two phenomena that seemed alienated from each other and closed as if in two spheres: between music and life" [7]. Concentrating all the trends and crises of romanticism in the music of the second half of the XIX century, the work of the composer as a reformer demonstrates current creations of the relentless desire to transform the world around, which encourage artists to different creative reactions to the collision of modern life, which, in turn, involves others in understanding its essence.

\section{СПИСОК ВИКОРИСТАНИХ ДЖЕРЕЛ}

1. Вагнер Р. Избранные работы / Р. Вагнер ; сост И коммент. И. А. Барсовой и С. А. Ошерова ; Вступ. ст. А. Ф. Лосева. - М. : Искусство, 1978. -695 с
2. Вагнер Р. Опера и драма [Электронный ресурс] / Р. Вагнер // Избранные работы. - М., 1978. - Режим доступа : http://teatr-lib.ru/ Library/Wagner/ Izbr/ \# Toc212715559

3. Галь Г. Брамс, Вагнер, Верди. Три мастера - три мира : в 3 ч. 4. 2. Рихард Вагнер [Электронный ресурс] / Г. Галь. Режим доступу: http://wagner.su/book/export/html/92

4. Гегель Г. В. Ф. Лекции по эстетике / Г.В.Ф.Гегель // Эстетика : в 4 т. - М. : Искусство, 1968. - Т. І. - 330 с.

5. Ильенков Э. Заметки о Вагнере / [Електронний ресурс] / Э. Ильенков. Режим доступу: http://www.wagner.su/node/141

6. Лосев А. Исторический смысл эстетического мировоззрения Рихарда Вагнера [Электронный ресурс] / А. Лосев // Философия. Мифология. Культура. - М. : Политиздат, 1991. - С. 275-314. - Режим доступа : http://teatr-lib.ru/Library/Wagner//zbr/\#_Toc212715552

7. Ницше Ф. Рихард Вагнер в Байрейте [Электронный ресурс] / Ф. Ницше // Сочинения В 3 т. Т. 2: "Странник и его тень". - Москва "REFL-book", 1994. - Режим доступа : http://www.wagner.su/node/173

\section{REFERENCES}

1. Vagner, R. (1978). Selected works. Moskow, Iskusstvo (in Russian)

2. Vagner, R. (1978). Opera and drama. In Selected works. Retrieved from http://teatr-lib.ru/Library/Wagner/ Izbr/ \#_Toc212715559 (in Russian)

3. Gal', G. (1986) Tri mastera - tri mira. Rihard Vagner [Three masters - three worlds. Richard Wagner]'. Retrieved from http://wagner.su/book/ export/ html/92

4. Gegel', G.V.F. (1968). Lectures on aesthetics. In 4 V, V 4. Moskow, Iskusstvo (in Russian).

5. Il'enkov, E. (1984) Zametki o Vagnere [Notes on Wagner]. Retrieved from http://www.wagner.su/node/141

6. Losev, A. (1991) Istoricheskij smysl esteticheskogo mirovozreniya Riharda Vagnera [The historical meaning of the aesthetic worldview of Richard Wagner]. Retrieved from http://teatr-lib.ru/Library/Wagner/lzbr/ \#_Toc212715552 (in Russian)

7. Nietzsche, F. Richard Wagner in Bayreuth. Retrieved from http://www.wagner.su/node/173 (in Russian)

Received Editorial Board 14.12.21

І. В. Живоглядова, канд. філос. наук, доц.

Київський національний університет імені Тараса Шевченка,

вул. Володимирська, 60, м. Київ, 01033, Україна

\section{КУЛЬТУРА Й ОСОБИСТІСТЬ: Р. ВАГНЕР "МІЖ МУЗИКОЮ ТА ЖИТТЯМ"}

Сучасні тенденції розвитку культури, ї̈ мистецької складової, загострили питання актуальності глибокого вивчення світової та національної спадщини. У статті здійснено аналіз життєтворчості видатної особистості - Р. Вагнера (1813-1883), з притаманною їй суперечливістю, складністю, багатогранністю, як репрезентації креативного потенціалу участі творчої особистості в процесах культуротворчості. Інтегративний культурологічний аналіз специфіки його композиторської діяльності як культурного феномена дозволяє висвітлити роль митця, мислителя, реформатора у просторі функціонування певної культурної, зокрема романтичної, традиції, дослідити суб'єктивний досвід перетворення мистецтва на культурну практику трансформації і вдосконалення суспільства.

Зазначається, що талант митця дозволяє повернути факт об'єктивної реальності в такому ракурсі, у якому б "заграла" його всезагальна одиничність у світлі загальної перспективи розвитку. Творчість є тим способом, який розширює можливості творчої особистості в розкритті безлічі різних граней буття. Відкриваючи нові напрями буття, творча особистість розиирює горизонти індивідуального досвіду, набуває елементів нової самосвідомості, самовідчуття. Це приводить, у свою чергу, до оновленої дії. Водночас творець збагачує саму дійсність, розвиваючи їі внутрішні потенції, створюючи цінності принципово нової якості. Творча діяльність з самого початку організується і регулюється формами, які мають універсальний характер. Ці форми є, в свою чергу, продуктом такої ж довгої "дистиляції", як і логічні форми, категорії логіки. Одночасно у вільній творчості завжди присутня більш-мени очевидна індивідуальна варіація тих форм діяльності, які вже формалізовані, виражені в жорстко однозначних формулах.

Аналіз вагнерівських творів виявляє, як, відштовхуючись від кращих зразків традиційного мистецтва минулого і теперішнього, композитор прагнув до адекватного втілення в художніх образах проблем, що ним усвідомлювалися, продовжуючи великі традиції і запроваджуючи істотні нововведення. Розвиток культури дуже гостро виявив дилему суперечливого становища митця і самого мистецтва в тогочасному суспільстві. Творча спадщина Р. Вагнера постала в якості своєрідного авторського бачення щодо сучасної йому культури, на яку, внаслідок її індивідуалістичної природи, чекає, на думку композитора, сумне майбутнє. На прикладі життєтворчості митця аналізується антропокреативний потенціал взаємодії культури й особистості. Зосереджуючи всі тенденції розвитку і кризи романтизму в музиці другої половини XIX століття, творчість композитора-реформатора демонструє актуальні для сьогодення креації з незупинного прагнення до перетворення навколишнього світу, які спонукають митців до різних типів творчих реакцій на колізії сучасного їм життя, що, в свою чергу, долучає інших до розуміння його суті.

Ключові слова: Р. Вагнер, творча особистість, реформаторство, культура романтизму, музична культура, оперна творчість, музична драма.

И. В. Живоглядова, канд. филос. наук, доц. Киевский национальный университет имени Тараса Шевченко, ул. Владимирская, 60, г. Киев, 01033, Украина

\section{КУЛЬТУРА И ЛИЧНОСТЬ: Р. ВАГНЕР "МЕЖДУ МУЗЫКОЙ И ЖИЗНЬЮ"}

Современные тенденции развития культуры, ее художественной составляющей, актуализировали вопросы глубокого изучения мирового и национального наследия. В статье осуществлён анализ жизнетворчества выдающейся личности - $P$. Вагнера (1813-1883), с присущей ей противоречивостью, сложностью, многогранностью, в качестве репрезентации креативного потенциала участия личности в процессах культуротворчества. Интегративный культурологический анализ специфики его композиторской деятельности как культурного феномена позволяет осветить роль художника, мыслителя, реформатора в пространстве функционирования определенной культурной, в данном случае романтической, традиции, исследовать субъективный опыт превращения искусства в культурную практику трансформации и совершенствования общества. На примере творчества немецкого композитора анализируется антропокреативный потенциал взаимодействия культуры и личности. Сосредоточивая все тенденции развития $и$ кризиса романтизма в музыке второй половины ХІХ века, творчество Р. Вагнера, композиторареформатора, демонстрирует актуальные для современности действия по непрерывному стремлению к совершенствованию окружающего мира, которые побуждают художников к разным типам творческих реакций на коллизии современной им жизни, что, в свою очередь, приобщает других к пониманию ее смысла.

Ключевые слова: Р. Вагнер, творческая личность, реформаторство, культура романтизма, музыкальная культура, оперное творчество, музыкальная драма. 